\title{
MULTIPLE ENVIRONMENT ASSESSMENT OF ARTIFICIAL PROFILES OF RECLAIMED MINELANDS
}

\author{
Kharytonov M. M., Klimkina I. I., Wiche O.
}

\section{INTRODUCTION}

The land cover is subject to significant damage during mining operations in open pit operations. As a result, the territories that remain after the extraction of mineral raw materials are usually wastelands with areas of exposed land, loose piles of disturbed soil and large volumes of dumps brought to the surface of rocks ${ }^{1,2}$. High-quality ores are drying up, the content of useful components is decreasing, the share of waste and waste rock is constantly growing. Most of the mining waste comes into active interaction with the environment (lithosphere, atmosphere, hydrosphere and biosphere). All mining wastes are subjects to changes in physical, chemical and biological properties ${ }^{3}$. New environmentally hazardous substances can form in the storage areas of these wastes and cause a greater threat to the environment ${ }^{4}$. Land reclamation is a complex of engineering, mining, land reclamation, biological, sanitary and other measures aimed at returning the territories violated by industry to various uses: forest, agricultural and recreational land reclamation. The complex of reclamation works takes place in several stages. The main stages are mining and biological reclamation. Mining reclamation is considered the most mass- and energy-intensive stages ${ }^{5}$. This is due to the movement and laying in a certain order of large masses of rocks and removed before the

${ }^{1}$ Sheoran V., Sheoran A.S., Poonia P. Soil reclamation of abandoned mine land by revegetation: a review. International Journal of Soil, Sediment and Water, 2010. 3(2), Art. 13. URL: http://scholarworks.umass.edu/intljssw/vol3/ iss2/13

${ }_{2}$ Menйndez J., Loredo J. Reclamation of Degraded Landscape due to Open Pit Coal Mining: Biomass for Renewable Power Plants. WSEAS Transactions on Environment and Development. 2018. № 14. P. 251-255. URL: http://www.wseas.org/multimedia/journals/ environment/2018/a505915-aav.php

${ }^{3}$ Borůvka L., Vacek O., Jehlička J. Principal component analysis as a tool to indicate the origin of potentially toxic elements in soils. Geoderma. 2005. № 128 (3-4). P. 289-300. https://doi.org/10.1016/j.geoderma.2005.04.010

${ }^{4}$ Navarro M.C., Pérez-Sirvent C., Martínez-Sánchez M.J., Vidal J., Tovar P.J. \& Bech J. Abandoned mine sites as a source of contamination by heavy metals: A case study in a semi - arid zone. Journal of Geochemical Exploration. 2008. № 96(2-3), P. 183-193. https://doi.org/10.1016/j.gexplo.2007.04.011

Kuter N. Reclamation of degraded landscapes due to opencast mining. In Advances in Landscape Archtecture. Chapter 2013. № 33. P. 823-858. http://dx.doi.org/10.5772/55796 
development of the humus layer of soil ${ }^{6}$. The most difficult work is related to increasing the fertility of the upper layer of dumps, improving its hydrophysical properties. The possibility of migration of acid solutions and toxic salts to the surface of the dump is not excluded if toxic rocks are removed to the daily surface. The ultimate goal of the mining stage of reclamation is to create an underlying layer, which consists of overburden rocks, to cover them a humus layer of soil or potentially fertile rocks suitable for biological reclamation to its surface. Mining rocks are brought to the surface during process of manganese ore mining. The soil mass is taken off, piled up and heaped onto the land after the rock has been replaced. Substrates formed in this way can be attributed to the category of technosol. Technosol are soils dominated or strongly influenced by humanmade materials and correspond to soils whose properties and pedogenesis are dominated by technical origin. The biological stage of reclamation is carried out after the full completion of the mining stage. This stage involves the restoration and formation of the soil cover, the accumulation of humus and nutrients. Crops of perennial legumes and grasses or their mixtures contribute to this process. Favorable ecological and biochemical conditions are created for soil genesis due to the stage of biological reclamation ${ }^{7,8}$.Phytostabilization and phytoextraction methods are successfully used for detoxification and removal of toxic metals from dumps ${ }^{9}$. The introduction of various meliorants and chelates contributes to a more intensive absorption of heavy metals by plants from technozems ${ }^{10,11}$. The responses of living organisms are used to evaluate the parameters of the environment. Changes in physiological, biochemical, genetic, morphological, or immune systems occur in an organism that is

${ }^{6}$ Vondráčková T., Voštová V. \& Kraus M. Mechanization for Optimal Landscape Reclamation. IOP Conference Series: Earth and Environmental Science, 95, Art. 022042. http://doi.org/10.1088/1755-1315/95/2/022042

Kharytonov M.M., Resio Espejo J.M. Prospects of the Nikopol manganese basin rocks using for land reclamation. Gruntoznavstvo, 2013. Vol. 14 (1-2). P. 78-86. URL: http://www.ussj.cv.ua/2013_t14_1-2/index.html

${ }^{8}$ Gould A.B., Hendrix J. W., Ferriss R. S. Relationship of mycorrhizal activity to time following reclamation of surface mine land in western Kentucky. I Propagule and spore population densities. Canadian Journal Botany. 1996. \# 74, P. 247-261. https://doi.org/10.1139/b96-030

${ }_{9}$ Macci C., Doni S., Peruzzi E., Bardella S. Filippis, G., Ceccanti B., Masciandaro G. A real-scale soil phytoremediation. Biodegradation, 2013. \#24(4). P. 521-538. https://doi.org/10.1007/s10532-012-9608-z

${ }^{10}$ Wong M.H. (2003). Ecological restoration of mine degraded soils, with emphasis on metal contaminated soils. Chemosphere. 2017. № 50(6). P. 775-780. https://doi.org/10.1016/S0045-6535(02)00232-1.

${ }^{11}$ Le S.H., Ji W., Yang H.J., Kang S.Y., Kang D.M. Reclamation of mine-degraded agricultural soils from metal mining: lessons from 4 years of monitoring activity in Korea. Environ. Earth Sci. 2017. № 76, Art. 720. https://doi.org/10.1007/s12665-017-7076-9 
contaminated. Different organisms can serve as test objects ${ }^{12}$, simplest ${ }^{13}$, invertebrates ${ }^{14}$ and perennial grasses ${ }^{15}$.The main goal of the research was a comprehensive physical, chemical, and bioindicational assessment of rocks affected by weathering and soil formation processes.

\section{Materials and methods}

Several model field experiments were settled in Pokrov and Pavlograd land reclamation experimental stations of DSAEU situated in Dnipropetrovsk province.

There are 9,000 ha of mined land with soil replaced in the Nikopol manganese region, but most has had ineffective reclamation. Another 10,000 ha or more exists without soil replace-ment (mostly from mining operations more than 30 years ago), and an estimated additional 150,000 ha or more in Nikopol region suffers significant adverse affects from the nonrestored mined land. There are thousands of smaller quarries where building materials are extracted in addition to mineral mines in various places of country. The objects of the first case study in Pokrov land reclamation station were different - age overburden rocks represented by loess - like loam (LLL), red - brown clay (RBC), gray-green clay (GGC), dark gray clay (DGC), as well as two black soil. These rocks of manganese ore basin are presented the holocene, postpliocene, neogen and paleogen deposits. These substrata were involved in long term plant melioration stage to transform them to "young soils" ". It allowed getting beneficial effects due to fertilizing activities of developing soil microbial communities. Several decades of previous work at DSAEU has demonstrated that the early stages of reclaiming abandoned mined lands require the use of legumes followed by legume-grass mixes. This use for hay/forage is the most appropriate transition to profitable field crop production from the bare, drastically

${ }^{12}$ Horvath B., Gruiz K., Sara B. Exotoxicological testing of soil by four bacterial biotests. Toxicological and Environmental Chemistry. 1997. № 58(1-4). P. 223-235. https://doi.org/10.1080/02772249709358412

${ }^{3}$ Lugovaya Y.R., Orlova K.N., Litovkin S.V., Malchik A.G., Gaydamak M.A. Biotesting as a method of evaluating waste hazard in metallic mineral mining. Materials Science and Engineering, 2016. № 127. 1-7. https://doi.org/10.1088/1757$899 X / 127 / 1 / 012026$

${ }^{14}$ Hanger M., Romantschuk M., Penttinen P-P., Egfors A., Marchand C., Augustsson A.. Assessing toxicity of metal contaminated soil from glassworks sites with a battery of biotests. Science of the Total Environment. 2018. P. 613-614, 30-38. https://doi.org/10.1016/j.scitotenv.2017.08.121

${ }^{15}$ Dubova L., Limane B., Muter O., Versilovskis A., Zarina Dz., Alsina I. Effect of nitroaromatic compounds on the growth of potted plants. Current Research Topics in Applied Microbiology and Microbial Biotechnology. 2009. 24-28. https://doi.org/10.1142/9789812837554_0005

${ }_{16}$ Tarika A.G., Zabaluev V.O. Mine land reclamation strategies in the Nikopol manganese ore basin (Central Steppe of Ukraine): Using replaced mining overburden in agriculture. 16th Int'l Conference, Society for Ecological Restoration, August 24-26, 2004, Victoria, Canada. 
disturbed soil that remains after mining operations. After biological reclamation using forage production for a total of 18-30 years, field-crop production can be prof-itably sustained if reasonable amounts of fertilizer are applied. The rhizobium-legume association contributes substantial $\mathrm{N}$ to the current and future $\mathrm{N}$ re-quirements of the non-legumes in the system.

Our previous study showed that the content of heavy metals in cultivated in local rocks grasses does not exceed norms of maximum permissible concentration $^{17}$ (Kharytonov, 2007). Six models of mineland biological reclamation have been developed and tested in several mining regions by the department of soil science of DSAEU. The worked out and tested land reclamation schemes encompass: a) growing the full range of typical crops of this zone (to obtain yields equal to those on lightly-eroded black soil); b) creation of young soils with $10-30 \%$ higher yield than normal restoration; c) growing crops on restored soils with phytotoxic or otherwise undesirable subsoils; d) growing pasture grasses on restored soils without replacement of the chernozem topsoil; and e) creation of tree plantations. The long-term effects of melioration crops have dramatically improved bio-weathering of rocks, phytomeliorated rocks fertility growth, and other processes.

The land reclamation scheme in Pavlograd research station of DSAEU provided the second case study of the overlapping mine dumps creation with different soil mass layers of black soil with the absence and presence of a screening layer of loess like loam (Fig. 1).

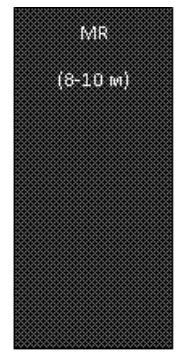

1

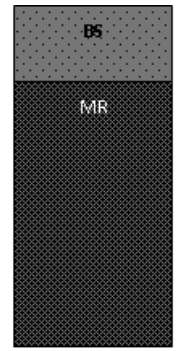

2

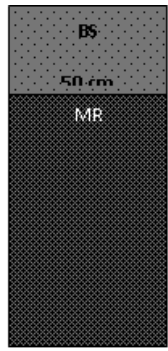

3

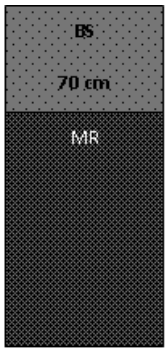

4

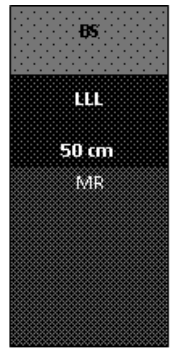

5

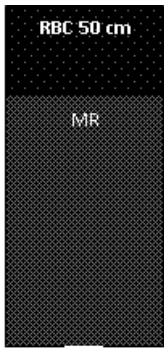

6

Fig. 1. Artificial profile of heaps land reclamation in coal mining region

The basis of the reclamation sites was formed by a mining rocks layer of $(8-10 \mathrm{~m})$ covered with various capacities of black soil or rock substrates. The artificial profiles of heaps land reclamation with the application of

\footnotetext{
${ }^{17}$ Kharytonov M. Geochemical assessment of reclaimed lands in the mining regions of Ukraine. NATO ARW Soil chemical pollution, risk assessment, remediation and security. Springer.Printed in the Netherlands. 2007. P. 57-60.
} 
$30 \mathrm{~cm}, 50 \mathrm{~cm}$, and $70 \mathrm{~cm}$ of black soil (no. 2, 3, and 4) and $50 \mathrm{~cm}$ of loess like loam (no. 5) and red-brown clay (no. 6) were studied.

Samples of plant material and soil substrates were dried, processed and prepared for physical and chemical analysis in accordance with standard methods for spectrophotometric and ICP-MS analyses. All analyses were performed in 5-fold repetition. Soil samples were brought to an air-dry condition. Soil water extracts - to the ratio of $1: 10 . \mathrm{pH}$ and conductivity were measured using a $\mathrm{pH}$ meter and portable conductometer. The quantitative content of $\mathrm{NO}_{3}^{-}, \mathrm{NH}_{4}{ }^{+}$and $\mathrm{PO}_{4}{ }^{3-}$ ions was determined by photometric method according to German standards DIN-Norm including DIN 38405-9, DIN 38406-5 and DIN EN ISO 6878. The gross and watersoluble content of trace elements was determined using the inductively coupled plasma mass spectrometry (ICP-MS) method at the laboratory of the Institute of biological Sciences at the Technical University "Freiberg Mining Academy". Preparation of samples for analysis of the gross content of trace and rare elements was carried out in accordance with ISO 11464: 1994 and ISO 14869-1:2005 by dissolving soil samples with acid melting ${ }^{18,19}$. Excess of the norm for the content of heavy metals in the soil was determined using the pollution index ${ }^{20,21}$. Statistical processing of the research results was performed using the Microsoft Excel 2010 software package.

Rocks from past geological eras are brought to the surface after open mining. The processes of intensive chemical weathering begin due to the interaction of the surface layers of the air, hydro, and atmosphere. During recent decades, land reclamation in mining regions has been carried out as a one technological cycle. Technological processes of open field development are accompanied by soil disturbance, changes in hydrological and hydrogeological regimes, the formation of new terrain, and other qualitative changes that worsen the state of the environment ${ }^{22}$.

${ }^{18}$ Oliver Wiche, Balazc Szekely, Nicolai-Alexeji Kummer, Christin Moschner and Hermann Heilmeier. Effects of intercropping of oat (Avena sativa L.) with white lupin (Lupinus albus L.) on the mobility of target elements for phytoremediation and phytomining in soil solution. International Journal of Phytoremediation. 2016. DOI: 10.1080/15226514.2016.1156635.

${ }^{19}$ Oliver Wiche, Hermann Heilmeier. Germanium $(\mathrm{Ge})$ and rare earth element (REE) accumulation in selected energy crops cultivated on two different soils. Minerals Engineering. 2016. № 92: 208-215.

${ }^{20}$ Doležalová Weissmannová, H., Pavlovský, J. and Chovanec, P. Heavy metal Contaminations of Urban soils in Ostrava, Czech Republic: Assessment of Metal Pollution and using Principal Component Analysis. Int. J. Environ. Res. 2015. 9(2): 683-696. ISSN: $1735-6865$

${ }^{21}$ Lu S.G. and Bai S.Q. Contamination and potential mobility assessment of heavy metals in urban soils of Hangz, China: relationship with different land uses. Environmental Earth Science. 2010. 60: 1481-1490

${ }^{22}$ Legwaila I.A., Lange E., Cripps J. Quarry reclamation in England: a review of techniques. JASMR, 2015. № 4(2), 55-79. http://doi.org/10.21000/ JASMR15020055 


\section{Forecast of the duration of formation of the moisture reserve in reclamation options with artificial clay aquiclude}

The forecast of the duration of the formation of the moisture reserve in the case of artificial water aquiclude was performed for the conditions of the Northern Steppe of Ukraine, taking into account the difference between precipitation and evaporation. The change in the groundwater level is indicated as $\Delta \mathrm{h}^{23}$ (Kharytonov, 2013).

$$
\Delta h=\frac{\varepsilon \cdot t}{\mu}, \mathrm{m} / \mathrm{year},
$$

where, $\varepsilon$ - infiltration nutrition in natural conditions; $t$ - time, days; $\mu-$ coefficient of lack of soil saturation in the aeration zone.

Moisture transpiration velocity (V) formula was applied for comparison of the components of rain precipitation and moisture losses due to evaporation and vegetation transpiration in agroecosystem:

$$
\mathrm{V}=\frac{P-(E+T)}{1000 \cdot D},
$$

where $P$ is rain precipitation, $m m, E$ is evaporation, $m m, T$ is transpiration (moisture transfer with crops harvest), $D$ is the amount of days in a year. Moisture transpiration with crops harvest was calculated by multiplying annual crops harvest to water absorption ratio. The results of calculations of the ground water rise time to the day surface for profiles with a water aquiclude at three land reclamation stations of DSAEU are shown in the table 1. It should be noted that the rock materials ability for using as a water aquiclude depends on the specific geological conditions of mineral deposit exploration in each case. Red-brown clay can be used in Volnogorsk and Pavlograd mining regions, gray-green and green free carbonated clay in Pokrov city. It is necessary to provide the creation of artificial drainage in order to avoid any risk of swamping during reclamation profile forming with a water aquiclude. Restoration of disturbed land means the creation of a flat terrain with slopes of the earth's surface, from $0^{0} 30$ seconds to $1.5^{0}$, the organization of runoff and removal of precipitation.

${ }^{23}$ Kharytonov M., Mitsik O., Stankevich S., Titarenko O. 2013. Geomining site environment assessment and reclamation along coastal line of the Kerch Peninsula NATO Science for Peace and Security. Series C: Environmental Security, A. Vezirogluand M.Tsitskishvili (eds.). Chapter 27. P. 325-336. URL: http://link.springer.com/chapter/ 10.1007/978-94-007-6152-0_27 
Calculations of the time of formation of reserve moisture in reclamation profiles with artificial clay aquiclude

\begin{tabular}{|c|c|c|c|}
\hline \multirow{2}{*}{ Station } & Profile & $\begin{array}{c}\text { Загальна потужність } \\
\text { штучного профілю, см }\end{array}$ & t, year \\
\hline \multirow{5}{*}{ Vylnogyrsk } & 30 cm LLL & 30 & 1.3 \\
\cline { 2 - 4 } & $\begin{array}{c}10 \mathrm{~cm} \text { Sand + 30 } \\
\text { cm LLL }\end{array}$ & 40 & 4.2 \\
\cline { 2 - 4 } & $\begin{array}{c}\text { 30 sand + 40 LLL + } \\
\text { 50 BS }\end{array}$ & 120 & 13.4 \\
\cline { 2 - 4 } & 50 LLL + 50 BS & 100 & 5.1 \\
\hline Pokrov & 50 LLL + 50 BS & 100 & 6.1 \\
\hline Pavlograd & 50 LLL + 50 BS & 100 & 6.6 \\
\hline
\end{tabular}

Notes: $L L L$ - loess-like loam; BS - black soil; $t$-time of formation of the reserve moisture, years

This is a guarantee of restoration of disturbed lands due to the process of forming a reclaimed layer with a capacity of 1.0-1.2 m, using the rocks most suitable for crops cultivation. Loess-like and red-brown loams with 34-44\% silt content meet these conditions. Meanwhile, red-brown loams in natural conditions are water-containing rocks of the upper waters and lie above water-resistant red-brown clays. This is why they are often salted. Therefore, a more susceptible way is to use them in a mixture with loess like loam. The process of land reclamation in the conditions of the steppe zone of Ukraine makes sense if the special measures for drainage management to avoid runoff and precipitation removal were provided. The use of an artificial water barrier can be considered as a low-cost water saving technology. Incorporation of artificial drainage is a necessary measure to protect the mine workings from the rise of groundwater and drip irrigation application.

\section{Forecast of ground water level dynamics taking into account natural lateral spreading for reclaimed dump without drainage with irrigation}

The forecast of the dynamics of the ground water level (taking into account the natural lateral spreading) was carried out for a reclaimed dump with a width of $100 \mathrm{~m}$ and a length of $200 \mathrm{~m}$. The hydrodynamic scheme "rectangular irrigation section in an unlimited reservoir" can be applied in this $\operatorname{case}^{24}$ (Fig. 2).

${ }^{24}$ Rudakov V.K. Methods of forecast calculation of irrigation impact on ground water regime. Issues of hydrogeological forecasts in connection with land irrigation and water supply. Issues of Scientific Research DSU. Dnepropetrovsk, 1970.Vol. 3. P. 5-97 (in Russian) 


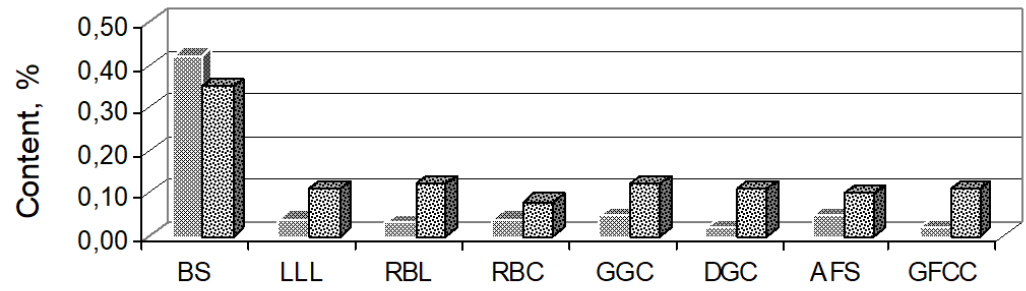

HA 圈FA

Fig. 2. Scheme "rectangular irrigation plot in an unlimited layer"

This scheme solution is as follows:

$$
z=0,25 \frac{\varepsilon \cdot t}{\mu}\left[I\left(\eta_{, x} m_{1}\right)-I\left(\eta_{x}, m_{2}\right)-I\left(\xi_{x}, m_{3}\right)+I\left(\xi_{x}, m_{4}\right)\right]
$$

where $z$ - increase in water level under the influence of infiltration. Value of coefficient $m$ according to formula (3), the following:

$$
m_{1}=\frac{y+c}{x+b}=0.5 ; m_{2}=\frac{y-c}{x+b}=-0.5 ; m_{3}=\frac{y+c}{x-b}=-0.5 ; m_{4}=\frac{y-c}{x-b}=0.5 .
$$

Value of coefficient $\eta_{x}$ and $\zeta_{x}$ the following:

$$
\eta_{x}=\frac{x+b}{2 \sqrt{a t}}=0.64 ; \zeta_{x}=\frac{x-b}{2 \sqrt{a t}}=-0.64 .
$$

Initial data: $C=50 \mathrm{~m}, b=100 \mathrm{~m} ; t=365$ days.

Detailed function table $I$ was compiled according to the calculated data. We used the numerical values of the function when $m \leq 1$.

The calculation was performed for the maximum elevation point with coordinates: $\mathrm{x}=0, \mathrm{y}=0$. Calculation example:

$$
\begin{gathered}
I\left(\eta_{x}, m_{1}\right)=I(0.64: 0.5)=0.461 \\
z=0.25 \frac{\varepsilon \cdot t}{\mu}\left[I\left(\eta_{, x} m_{1}\right)-I\left(\eta_{x}, m_{2}\right)-I\left(\xi_{x}, m_{3}\right)+I\left(\xi_{x}, m_{4}\right)\right]= \\
=\frac{0.25 \cdot 1.64 \cdot 10^{-4} \cdot 365}{0.03} \cdot 0.461 \cdot 4=0.922 \mathrm{~m} .
\end{gathered}
$$


So, the rise of groundwater will be $0.922 \mathrm{M}$.

Dynamics of ground water level in the presence of drainage taking into account natural lateral spreading

The level of underground outflow of irrigation water outside the zone of formation of the initial "hump" (Fig. 3) for time t can be represented by the equation:

$$
\begin{aligned}
z= & 0.25 \frac{\varepsilon \cdot L^{2}}{T}\left[F\left(x_{1}^{1}, y_{1}, \tau\right)+F\left(x_{1}^{11}, y_{1}, \tau\right)-F\left(x_{2}^{1}, y_{1}, \tau\right)-F\left(x_{2}^{11}, y_{1}, \tau\right)-\right. \\
& \left.F\left(x_{1}^{1}, y_{2}, \tau\right)-F\left(x_{1}^{11}, y_{2}, \tau\right)+F\left(x_{2}^{1}, y_{2}, \tau\right)+F\left(x_{2}^{11}, y_{2}, \tau\right)\right]
\end{aligned}
$$

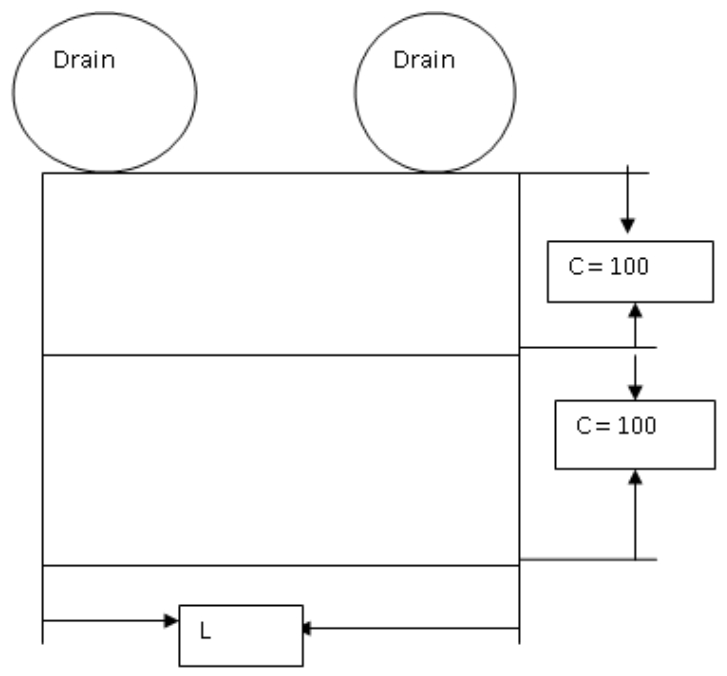

Fig. 3. Scheme of underground outflow of irrigation water outside the site

Initial data. Plot dimensions: width $-100 \mathrm{~m}$, length $-200 \mathrm{~m}$

$$
\begin{gathered}
b_{1}=0 ; b_{2}=L, b_{1}<x<b_{2} ; b_{1}<x<L ;-c<y<c \\
\mathrm{~L}=100 ; \mathrm{C}=90 ; \mathrm{X}=50 ; \mathrm{Y}=0 ; b_{2}=L, b_{1}=0 .
\end{gathered}
$$

The solution (a rectangular section of infiltration in a formation-strip with boundaries of the 1st kind was used to assess the level of ground water, modified for the proposed scheme of reclamation of rock dumps with 
irrigation against the background of horizontal drainage. The solution has the form:

$$
\begin{gathered}
z=0,25 \frac{\varepsilon \cdot L^{2}}{T}\left[F\left(x_{1}^{1}, y_{1}, \tau\right)+F\left(x_{1}^{11}, y_{1}, \tau\right)-F\left(x_{2}^{1}, y_{1}, \tau\right)-F\left(x_{2}^{11}, y_{1}, \tau\right)-\right. \\
\left.-F\left(x_{1}^{1}, y_{2}, \tau\right)-F\left(x_{1}^{11}, y_{2}, \tau\right)+F\left(x_{2}^{1}, y_{2}, \tau\right)+F\left(x_{2}^{11}, y_{2}, \tau\right)\right],(5)
\end{gathered}
$$

where $F(x, y, z)$ - the tabulated function.

Value of coefficient $x_{1}^{1}, x_{1}^{11}, x_{2}^{1}$ and $x_{2}^{11}$ according to formula (3), the following:

$$
\begin{gathered}
x_{1}^{1}=\frac{x+b_{1}}{L}=0,5 ; x_{1}^{11}=\frac{x-b_{1}}{L}=0,5 ; x_{2}^{1}=\frac{x+b_{2}}{L}=1,5 \\
\text { та } x_{2}^{11}=\frac{x-100}{100}=-0,5 .
\end{gathered}
$$

The following sequence of calculations using the formula (5) is as follows:

$$
\begin{aligned}
& \tau=\frac{a \cdot t}{L^{2}} ; \mathrm{T}=2,2 ; \mathrm{A}=\frac{k_{1} \cdot m_{1}}{\mu_{1}}+\frac{k_{2} \cdot m_{2}}{\mu_{2}}=16,7 ; \mathrm{t}=1 \text { year; } \\
& \tau=\frac{a \cdot t}{L^{2}}=\frac{16,7 \cdot 365}{10000}=0,61 ; y_{1}=\frac{0+L}{100}=1,0 ; y_{2}=\frac{y-L}{L}=-1,0 ; \\
& F\left(x_{1}^{1}, y_{1}, \tau\right)= F(0,5 ; 1,0 ; 0,61)=0,0605 ; F\left(x_{1}^{11}, y_{1}, \tau\right) \\
&= F(0,5 ; 1,0 ; 0,61)=0,0605, \\
& F\left(x_{2}^{1}, y_{1}, \tau\right)= F(1,5 ; 1,0 ; 0,61)=0,015 ; F\left(x_{2}^{11}, y_{1}, \tau\right)= \\
& F(-0,5 ; 1,0 ; 0,61)=-0,06, \\
& F\left(x_{1}^{1}, y_{2}, \tau\right)= F(0,5 ;-1,0 ; 0,61)=0,06 ; F\left(x_{1}^{11}, y_{2}, \tau\right)= \\
& F(0,5 ;-1,0 ; 0,61)=-0,06, \\
& F\left(x_{2}^{1}, y_{2}, \tau\right)= F(1,5 ;-1,0 ; 0,61)=-0,015 ; F\left(x_{2}^{11}, y_{2}, \tau\right)= \\
& F(-0,5 ;-1,0 ; 0,61)=0,015,
\end{aligned}
$$

So, the rise of ground water against the background of drainage according to the formula (5) is determined after the calculations as follows: 


$$
\begin{gathered}
z=0,25 \frac{\varepsilon \cdot L^{2}}{T}\left[F\left(x_{1}^{1}, y_{1}, \tau\right)+F\left(x_{1}^{11}, y_{1}, \tau\right)-F\left(x_{2}^{1}, y_{1}, \tau\right)-F\left(x_{2}^{11}, y_{1}, \tau\right)-\right. \\
\left.F\left(x_{1}^{1}, y_{2}, \tau\right)--F\left(x_{1}^{11}, y_{2}, \tau\right)+F\left(x_{2}^{1}, y_{2}, \tau\right)+F\left(x_{2}^{11}, y_{2}, \tau\right)\right]= \\
0,25 \frac{1,64 \cdot 10^{-4} \cdot 10^{4}}{2,2} \cdot 0,286=0,05 \text { м } / \text { piк. }
\end{gathered}
$$

The calculation is made for a period of one and ten years. Thus, for one year, the rise against the background of drainage will be $0.05 \mathrm{~m}$, and for 10 years (stabilization time) $z=0.2 \mathrm{~m}$.

Irrigation justification was performed for a site located on the territory of the reclaimed heap of Zaporyzhya quarry of the Nikopol manganese ore deposit. The planned area of 16 hectares was planted with alfalfa. The substrates brought to the surface of the day surface were represented by a mixture of overburden rocks with different degrees of predominance of loess like, red-brown loams and clays. Alfalfa irrigation at the experimental site was performed using a sprinkler. Water was supplied to the sprinkler by a pump through a pipeline. The irrigation rate was $400-500 \mathrm{~m}^{3} / \mathrm{ha}$. The dynamics of the ground water level for the new reclamation station without drainage with irrigation of 16 ha (width $-200 \mathrm{~m}$, length $-800 \mathrm{~m}$ ) was quantitatively characterized by the hydrodynamic scheme (Fig. 4) "rectangular irrigation section in an unlimited layer".

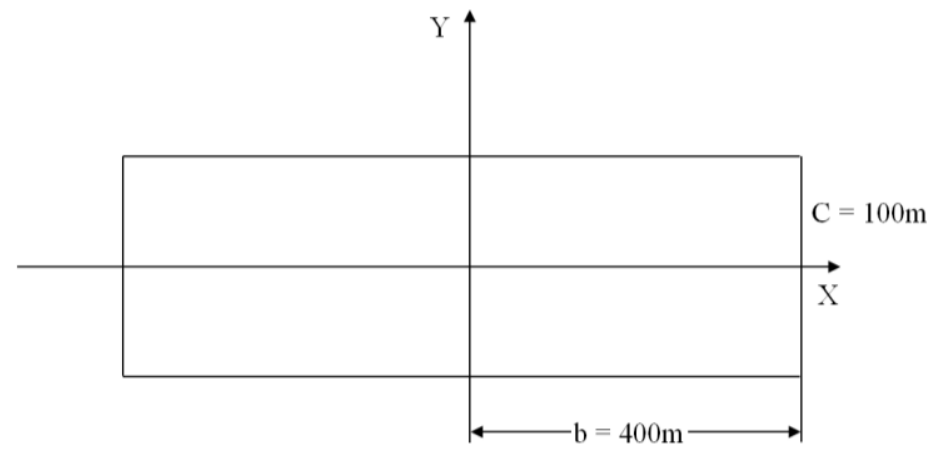

Fig. 4. Hydrodynamic scheme

"rectangular irrigation section in an unlimited reservoir"

Calculation for the point (maximum rising) $0.0(\mathrm{x}=0, \mathrm{y}=0)$ conducted according to the formula (3). Initial data: $C=100 \mathrm{~m}, b=400 \mathrm{~m}$; $t=365$ days. Calculation of coefficients $m, \eta_{x}$ and $\zeta_{x}$ according to formula (3), the following: 


$$
\begin{gathered}
m_{1}=\frac{y+c}{x+b}=\frac{0+100}{0+400}=0,25 ; m_{2}=\frac{y-c}{x+b}=\frac{0-100}{0+400}=-0,25 ; \\
m_{3}=\frac{y+c}{x-b}=\frac{0+100}{0-400}=-0,25 ; \\
m_{4}=\frac{y-c}{x-b}=\frac{0-100}{0-400}=0,25 ; \eta_{x}=\frac{x+b}{2 \sqrt{a t}}=\frac{0+400}{2 \sqrt{16,7 \cdot 365}}=\frac{400}{2 \cdot 78,07}=2,56 ; \\
\zeta_{x}=\frac{x-b}{2 \sqrt{a t}}=-0,64 \frac{-400}{156,14}=-2,56 .
\end{gathered}
$$

Calculation example: $I\left(\eta_{x}, m_{1}\right)=I(2,56: 0,25)=0,71$;

$$
\begin{gathered}
z=0,25 \frac{\varepsilon \cdot t}{\mu}\left[I\left(\eta_{, x} m_{1}\right)-I\left(\eta_{x}, m_{2}\right)-I\left(\xi_{x}, m_{3}\right)+I\left(\xi_{x}, m_{4}\right)\right]= \\
=\frac{0,25 \cdot 1,64 \cdot 10^{-4} \cdot 365}{0,03} \cdot 0,71 \cdot 4=1,42 \mathrm{~m} .
\end{gathered}
$$

The results of determining the $\mathrm{pH}$ reaction, anionic-cationic composition of water from potential sources for irrigation $(\mathrm{g} / \mathrm{l})$ are shown in table 2.

Assessment of the water chemical composition

Table 2

from potential irrigation sources

\begin{tabular}{|c|c|c|c|c|c|c|c|c|}
\hline \multirow{2}{*}{ Source } & $\mathbf{p H}$ & \multirow{2}{*}{$\begin{array}{c}\text { Salinity, } \\
\mathbf{g} / \mathbf{l}\end{array}$} & $\begin{array}{c}\mathbf{H C} \\
\mathbf{\mathbf { O } _ { 3 }}\end{array}$ & $\mathbf{C l}$ & $\mathbf{S O}_{\mathbf{4}}$ & $\mathbf{C a}$ & $\mathbf{M g}$ & $\mathbf{N a}$ \\
\hline Quarry lake & 8.0 & 5.17 & 0.32 & 1.14 & 2.44 & 0.46 & 0.75 & 0.06 \\
\hline $\begin{array}{c}\text { "Chortomly } \\
\text { k" lake }\end{array}$ & 8.19 & 0.44 & $\begin{array}{c}0.18 \\
9\end{array}$ & 0.091 & 0.072 & 0.04 & 0.048 & 0.028 \\
\hline Well & 8.10 & 1.26 & $\begin{array}{c}0.70 \\
8\end{array}$ & 0.161 & 0.134 & 0.06 & 0.159 & 0.066 \\
\hline
\end{tabular}

All analyzed water samples are evaluated as neutral and slightly alkaline according to the $\mathrm{pH}$ value. The waters of the quarry lake have a high level of mineralization. Assessing the suitability of water from potential sources for irrigation by the SAR coefficient allowed us to assert that they belong to the first type ( $\mathrm{SAR}=0--10)$. It is possible to dilute the waters of the quarry lake with another source with a low level of salinity taking into account the requirements for the quality of irrigation water $\mathrm{C} \leq 3 \mathrm{~g} / \mathrm{l}$. Dumping of dumps on quarries is carried out by a walking excavator with a volume $10-15 \mathrm{~m}^{3}$. Cones of deposited rocks have a non-uniform composition. Crushed rocks accumulate in the centre and at the top of the cone. More lumpy rocks are poured along the perimeters. Heterogeneity and randomness in the composition of dump rocks is observed with this method of dumping. This creates real prerequisites for uneven subsidence of the base on the surface of the dumps, as well as local subsidence in their body. In this regard, 
topographic and geodetic studies of intensive subsidence on reclaimed land were conducted. It was determined by 10 years observations after dumping. The amount of subsidence for individual points on the surface of the dumps is uneven and ranges from 0.3 to $1.88 \mathrm{~m}$. The area of subsidence reaches $16 \%$ of the total surface of the experimental site. It was obvious that the previously homogeneous land cover was deformed with depressions forming to provide situation for water accumulation. Analysis of heaps dumping with a walking excavator in places where studies of subsidence phenomena were conducted at the Zaporyzhya quarry showed that the technology of heaps forming causes the possibility of uneven subsidence. This technology heaps are cone-like ridge, where the rocks in the center of the cones are most densely spreaded (with a small coefficient friability), and on the periphery of cones - with the lowest density. The crumbling coefficient was 1.2, and the residual coefficient in the body of the dumps was about 1.05 . At the same time, the compaction coefficient during the dumping period reached $10 \%$. Calculations based on the established parameters showed that drawdowns can be about $5 \%$ of the capacity of dumps. This corresponds to the size of the drawdown of 3-3.5 m for the entire period of subsidence of dumps. In recent years, the Pokrovsky mining and processing plant has improved the technology of forming dumps in order to reduce subsidence and reduce the time of their occurrence. Extraction of manganese ore in the conditions of technogenic landscapes was carried out on three types of quarry, depending on the mining and geological conditions and the use of overburden and dump equipment. The first type - Zaporozhye, Shevchenko, North, Chkalovsky quarries. The second type - Bogdanovka pit, the third type Alexandria and Pokrov quarry. Quarries of the first and second types had a depth up to $80 \mathrm{~m}$, and the third type-with an opening capacity of up to $40 \mathrm{~m}$. Heap reclamation after seven years of surface levelling was involved in studies of suitability for irrigation works. Geodetic survey of the surface of the new heap, intended for irrigation, was carried out one year after the beginning of the annual (for four years) irrigation of alfalfa. The average height of the planned heap was $64.3 \mathrm{~m}$. The coefficient of variation, according to statistical processing of geodetic survey results (30 measurements of high-altitude marks of the dump surface) was $1.45 \%$. A comparison of the survey results, which was conducted a year later, did not reveal significant subsidence of the heap surface. The average height of the planned heap was $64.07 \mathrm{~m}$. The coefficient of variation was $1.6 \%$. The heap surface was planned again and covered with a $50 \mathrm{~cm}$ of black soil after four years of alfalfa cultivation taken in account that 7 years period is sufficient for natural compaction of the soil stage and the end of the stage of stabilization of the dump surface. The use of drip irrigation technologies was made at the depth of wetting of the top and sub-top soil layer. These systems are promising for organizing irrigation on reclaimed heaps after the necessary stage of surface stabilization. 


\section{The artificial profiles salinization assessment in two land reclamation stations}

The trend of slow salinization of the black soil layer indicates the need to ensure the wash mode of reclaimed lands irrigation in the conditions of the steppe zone of Ukraine. The field area of the Pokrovsky land reclamation station has a surface formed on deposits of less like loam (LLL), as well as red - brown and gray-green clays ((RBC and GGC). In addition, a $50 \mathrm{~cm}$ black soil (BS) was formed on a mixture of loess like loam (LLL) and red brown clays (RBC). An assessment of the salts profile distribution in rocks exposed to the surface shows that the salinity of the meter layer of rocks is in the range of $0.05-0.35 \%$ (Fig. 5).

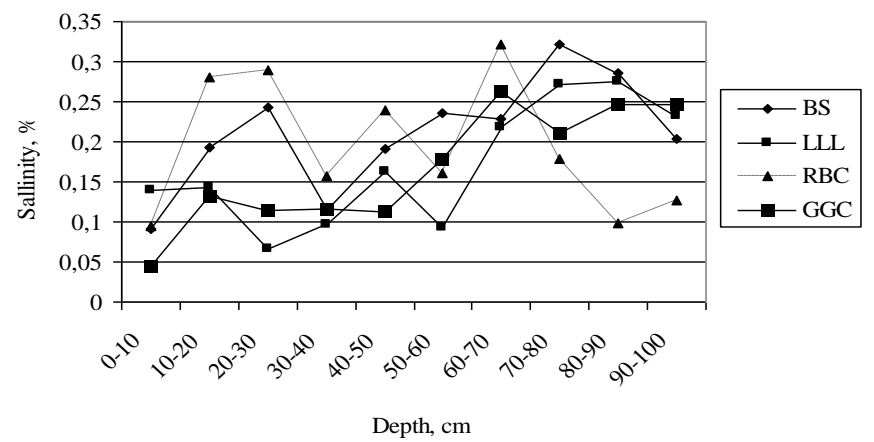

Fig. 5. Salts distribution in the black soil and rocks profile

The results of assessing of salts profile distribution in the site under long-term natural vegetation are shown in figure 6.

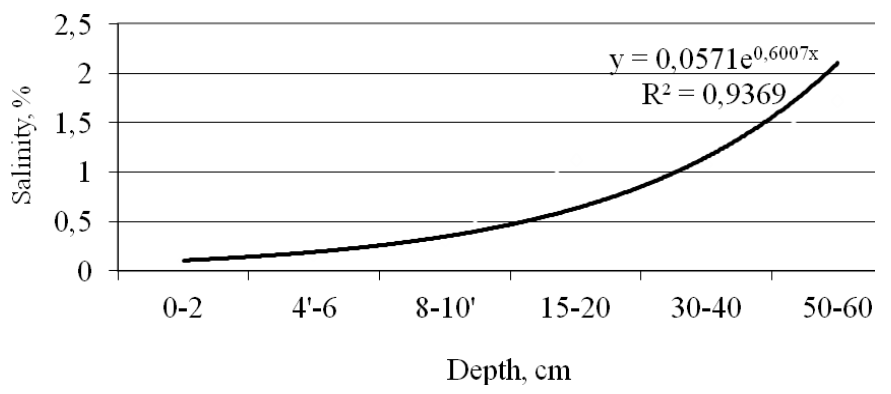

Fig. 6. Salts profile distribution in the site under long-term natural vegetation, \% 
These results indicate a negative impact of salted red-brown clays on the upper layers of the plant meliorated mixture of rocks. The results of studying the effect of long-term phytomelioration of legum and cereal crops mix on the distribution of water-soluble salts in top and sub top layers of rocks after one and two stages ( 1 and 2 stages) are shown in figure 7.

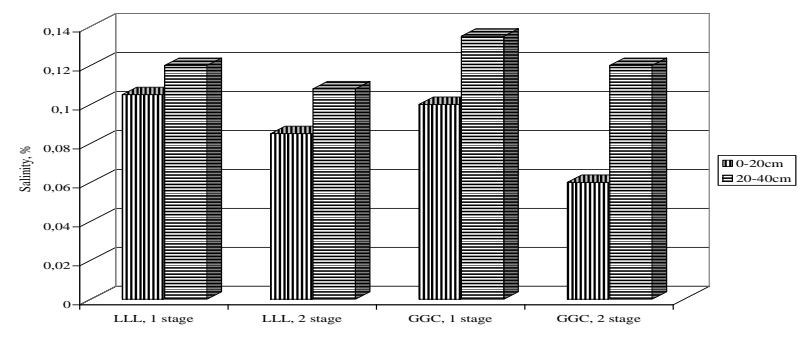

\section{Fig. 7. Profile distribution of salts in top and sub top layers of rocks depending on the stage of rocks phytomelioration, \%}

Decreasing of the content of water-soluble salts in the top of young soil layer after biological development indicates in favour of crop rotation with two stages of plant melioration and subsequent cultivation of cereal-legume grass mixture. The shown effect can be taken for further use during plant melioration of the heap surface that is formed from salted red-brown clays.

\section{Case study of salt migration in reclaimed land profiles in the coal-mining region of Western Donbass}

Research in the Western Donbass coal region was related to providing a comprehensive geochemical assessment of the mine heap reclamation ${ }^{25,26}$. Changes in soil $\mathrm{pH}$ along the reclaimed profile in profiles with different capacities of the black soil layer were studied (Fig. 8).

The obtained data confirm that the absence of a protective screen of loess like loam leads to rapid acidification of the soil solution of the soil layers due to the rapid passage of the rocks chemical weathering process on contact

${ }^{25}$ Kharytonov M.M. and Kroik A.A. Environmental Security of Solid Wastes in the Western Donbas Coal Mining Region, Ukraine. Environmental Security and Ecoterrorism, NATO Science for Peace and Security Series C: Environmental Security, H. Alpaset al. (eds.). 2011. P. 129-138.

${ }^{26}$ Klimkina I., Kharytonov M., Zhukov M. Trend Analysis of Water-Soluble Salts Leaching Along Surfaces of Reclaimed Mine Dumps in Western Donbass (Ukraine). Environmental Research, Engineering and Management. 2018. Vol 74. No 2. P. 82-92 
with the mine dump. The alkaline barrier is the main factor in changing the $\mathrm{pH}$ and profile salinization of reclaimed mine land ${ }^{27}$.

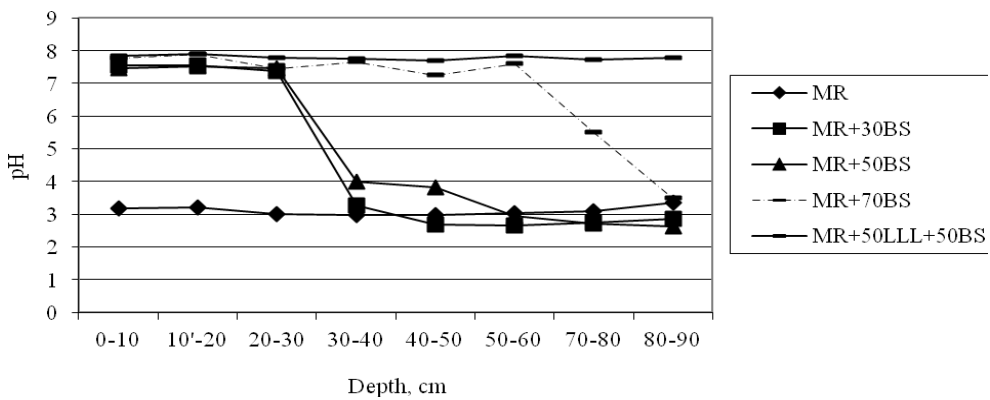

Fig. 8. Profile pH distribution with reclamation options

The introduction of a $50 \mathrm{~cm}$ layer of loess like loam in the MR+50BS trial led to a significant containment of the chemical weathering of the mine dump rocks (Fig. 9).

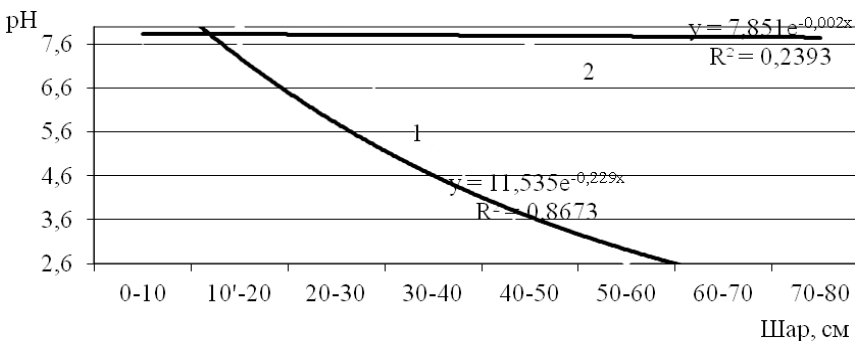

Fig. 9. Stabilization of the profile $\mathrm{pH}$ distribution due to application $50 \mathrm{~cm}$ of loess like loam per mine dump in trials:

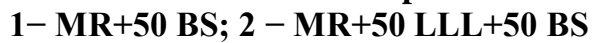

Therefore, $\mathrm{pH}$ stabilization in the MR+50 LLL+50 BS trial is possible within 7.7-7.9. Comparison of the obtained data allowed us to draw the following conclusion: the variant with a layer of loess like loam with the capacity of a $50 \mathrm{~cm}$ black soil layer $(\mathrm{MR}+50 \mathrm{LLL}+50 \mathrm{BS})$ is the most promising for reclamation at the disturbed Samara river floodplain. The

${ }^{27}$ Maiti S.K., Ghose M.K. Ecological restoration of acidic coal mine overburden dumps - on Indian case study. Land Contamination and Restoration. 2005. \# 13(4): 361-369. http:// dx.doi.org/10.2462/09670513.637 
results of chemical analysis data on the salts distribution along reclamation profiles with a loess-like loam layer are shown in figure 10 .

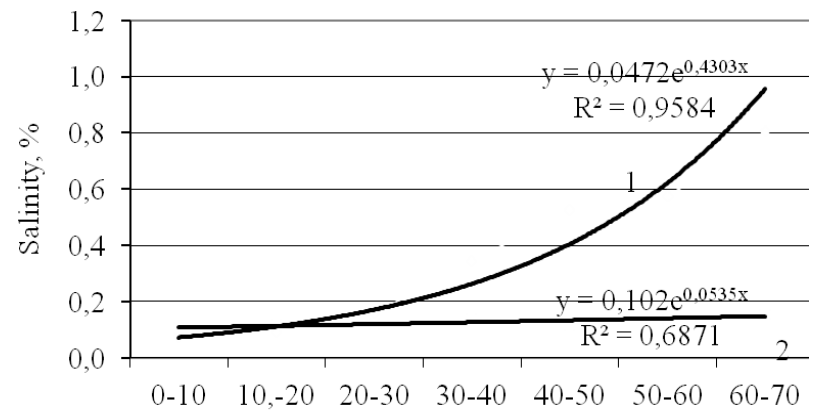

Depth, cm

Fig. 10. Influence of the geochemical screen on the salts distribution along two model profiles in the trials $\mathrm{MR}+50 \mathrm{~cm}$ BS (1) and MR+50 LLL+50 BS (2)

The study of the salts distribution along two model profiles with a layer indicates a significant containment of the salinity rate in the trial MR+50 LLL+50 BS.

\section{Assessment of the impact of profile salinization on the process of self-growth of reclaimed dumps}

Anthropogenic edaphotopes, formed during this period are significantly different from zonal soils of the level of fertility, physical, physico-chemical, agrochemical and other environmentally important factors. Quite often, such rocks contain phytotoxic compounds or are formed during their oxidation on the surface during the weathering process ${ }^{28}$.

One of the means of determining the suitability of technozems for growing crops is bioindication ${ }^{29,30}$.

An assessment of the natural overgrowth of two options for land reclamation plots no. 4 and no. 6) in the conditions of the Western Donbass

${ }^{28}$ Baderna D., Lomazzi E., Pogliaghi A., Ciaccia G., Lodi M., Benfenati E. Acute phytotoxicity of seven metals alone and in mixture: Are Italian soil threshold concentrations suitable for plant protection? Environmental Research. 2015. № 140. P. 102-111. https://doi.org/10.1016/j.envres.2015.03.023

${ }^{29}$ Nikolaeva O.V., Terekhova V.A. Improvement of laboratory phytotest for the ecological evaluation of soils. Eurasian Soil Sc., 2017. № 50(9). P. 1105-1114. https://doi.org/10.1134/S1064229317090058

Chaignon V., Hinsinger P. A Biotest for Evaluating Copper Bioavailability to Plants in a Contaminated Soil. Journal of Environmental Quality. 2003. № 32. P. 824-833. https://doi.org/10.2134/jeq2003.8240 
was provided. Two types of life forms (perennial herbaceous plants, biennials and annuals) were identified in the flora of the studied areas. The distribution of species composition by these types is shown in table 3 .

Table 3

The distribution of species according

to the types of life forms on the site no. 4

\begin{tabular}{|c|c|c|}
\hline \multirow{2}{*}{ Life forms } & \multicolumn{2}{|c|}{ Species number } \\
\cline { 2 - 3 } & Value & $\mathbf{\%}$ \\
\hline Trees & 0 & - \\
\hline Bushes & 0 & - \\
\hline Semi-shrubs & 0 & - \\
\hline Perennial herbaceous plants & 16 & 57.1 \\
\hline Biennials and annuals plants & 12 & 42.9 \\
\hline
\end{tabular}

Vegetation of the reclamation area no. 4 is represented mainly by meadow and weed groups. Analysis of the cenomorphic spectrum shows an absolute predominance of weed (ruderal) species in the vegetation cover. Their share is $44 \%$ of the total number of species. The second place in the number of weed - steppe species - 20\%. The proportion of plants introduced with the filling of floodplain meadow-boggy soil: aquants (4\%), pratants-halophytes $(12 \%)$, pratants $(7 \%)$ is small. One of the main factors that determine both the floral composition and the structural organization of plant communities is moisture. The analysis of hygromorphs revealed the predominance of mesoxerophytes in the vegetation cover (60\%), the share of mesophytes falls to $24 \%$. Filling of red-brown clay layer with $50 \mathrm{~cm}$ thick on the site no. 6 was carried out on the mine rock. Vegetation of the first stage of self-growth is characterized as weed. The total projective coverage is about 5\%. In total, 34 species of vascular plants belonging to 16 families were found in the studied territory. Two types of life forms were identified in the studied flora of the site: perennial herbaceous plants and biennials and annuals plants. The distribution of species composition by type of life forms is shown in table 4.

Table 4

The distribution of species according to the types of life forms on the site no. 6

\begin{tabular}{|c|c|c|}
\hline Life forms & \multicolumn{2}{|c|}{ Species number } \\
\hline & Value & $\%$ \\
\hline Trees & 0 & - \\
\hline Bushes & 0 & - \\
\hline Semi-shrubs & 0 & - \\
\hline Perennial herbaceous plants & 18 & 52.9 \\
\hline Biennials and annuals plants & 16 & 47.1 \\
\hline
\end{tabular}


According to the data obtained, the distribution of life forms is similar to the site of reclamation no. 4 and corresponds to the weed stage of selfgrowth succession. The vegetation of the reclamation area no. 6 is mainly represented by weeds and weeds-steppe groupings. In the vegetation cover, as in plot no.4, there is an absolute predominance of weed (ruderal) species $40 \%$ of the total number. The second place in the number is occupied by weed-steppe species $-18 \%$. Other categories of plants are brought from adjacent areas of the floodplain: aquanta, psammophyte, patanty. Mesoxerophytes (52\%) predominate in the hygromorphic vegetation spectrum of the reclamation plot no. 6 of the Western Donbass, which includes most weeds (Fig. 11). Mesophytes are second (21\%), and xerophytes take third place $(15 \%)$. According to the data of the hygromorphic analysis, both studied areas are very close in terms of moisture level.

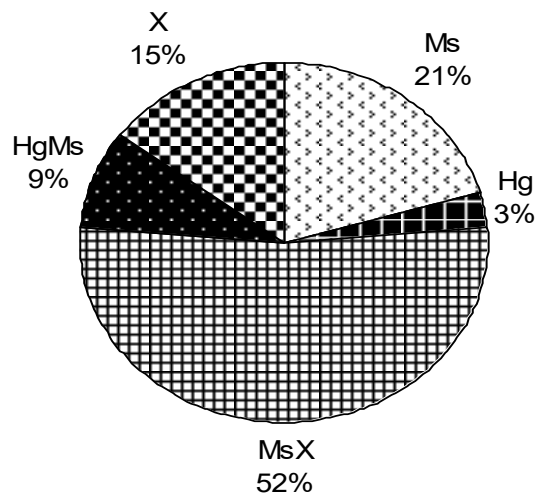

Fig. 11. Hygromorphic spectrum of the reclamation plot no. 6

The chosen direction of reclamation in both cases is the use of perennial for natural meadows and energy crops plantations ${ }^{31,32}$. The results of the study physico-chemical parameters of ground substrates from the reclamation plots indicate fluctuations in the $\mathrm{pH}$ of the soil from $6.0 \pm 0.58$ for plot no. 2 (which was formed a bulk layer of topsoil $30 \mathrm{~cm}$ ) to $8.4 \pm 0.17$ for the plot no. 6 (formed bulk layer of red-brown clay), increased conductivity from $13 \mu \mathrm{S} / \mathrm{cm}$ for plot no. 4 (which was formed a bulk layer of

31 Baranov V.I.. Knish I.B.. Blaida I.A.. Vaschuk S.P.. Gavriliak M.J. Cane phytoremediant of heavy metals in drainage ditch rock dump coal mines. Biol. Stud.: 2012. № 6(1). 93-100. https://doi.org/10.30970/sbi.0601.18

32 Boehmel C, Lewandowski I, Claupein W. Comparing annual and perennial energy cropping systems with different management intensities. Agricultural Systems. 2008. Vol. 96(1-3). P. 224-236. https://doi.org/10.1016/j.agsy.2007.08.004 
topsoil $70 \mathrm{~cm}$ ) to $104 \mu \mathrm{S} / \mathrm{cm}$ plot no. 6 . It should be noted that the specific electrical conductivity of water suspensions, such as black soil, ranges from 35 to $103 \mu \mathrm{S} / \mathrm{cm}$, and the arable soil layer is $24-25 \mu \mathrm{S} / \mathrm{cm}$. Electrical conductivity is mainly related to the mineral composition of the soil, its humidity, cation exchange capacity, salinity and organic matter levels.

It is known that soils are considered secure if the average content of $\mathrm{PO}_{4}{ }^{3-}$ is $500-1000 \mathrm{mg} / \mathrm{kg}$. The results indicate an insufficient level of the available form of phosphorus for plants in all test points. It ranges from $6.5 \pm 0.83$ to $7.7 \pm 0.94 \mathrm{mg} / \mathrm{kg}$. Soil concentrations of $\mathrm{NH}_{4}{ }^{+}$and $\mathrm{NO}_{3}{ }^{-}$depend on biological activity. Their level may vary depending on conditions such as temperature and humidity. Nitrates are easily leached from the soil by a large amount of precipitation. Typical concentrations of the cation $\mathrm{NH}_{4}{ }^{+}$in the soil are considered to be $0.2-1.0 \mathrm{mg} / \mathrm{kg}$, anion $\mathrm{NO}_{3}{ }^{-}-$concentrations that do not exceed $130 \mathrm{mg} / \mathrm{kg}$. The content of the cation $\mathrm{NH}_{4}{ }^{+}$in the soil of the experimental plots is within the range of $4.72 \pm 0.42$ to $6.2 \pm 0.36 \mathrm{mg} / \mathrm{kg}$, and the anion content $\mathrm{NO}_{3}{ }^{-}-$from $18.8 \pm 4,91$ to $41.3 \pm 12.32 \mathrm{mg} / \mathrm{kg}$. The results obtained indicate an insufficient amount of nitrogen and phosphorus forms available to plants.

The accumulation of trace metals in the soil over a period of time can lead to problems with excessive uptake of these elements by plants ${ }^{33,34,35,36}$. The excess of the content of 6 heavy metals (in descending order) was found after analyzing the content of 11 elements in the soil layer of $0-20 \mathrm{~cm}$, namely: $\mathrm{As}>\mathrm{Fe}>\mathrm{Co}>\mathrm{Zn}>\mathrm{Cu}>\mathrm{Cr}$.

\section{Results of the study of biogeochemical indicators for heavy metals in wild crops at reclamation sites}

In our research, samples of two spontaneously growing plant species were taken from reclamation sites: Bromopsis inermis (grows in all areas of reclamation), and Lathyrus tuberosus (found only on the 3rd plot with $70 \mathrm{~cm}$ black soil). Boneless rump (Bromopsis inermis) - perennial rootstock cereal species of winter-spring type of development. This is a valuable specie that is indispensable on slopes subject to water and wind erosion and can withstand flooding. The feed value of the grass is high. It is well eaten by all types of animals due to the high number of vegetative shoots. It grows well on different types of soil, acidic, saline and swampy soils are not suitable for

${ }^{33}$ LațoA., Radulov I., Berbecea A., Lațo K., Crista F.. The transfer factor of metals in soil-plant system. Research Journal of Agricultural Science. 2012. № 44 (3). P. 67-72.

${ }^{34}$ Hector M. Conesa, Michael W. H. Evangelou, Brett H. Robinson and Rainer Schulinю A Critical View of Current State of Phytotechnologies to Remediate Soils: Still a Promising Tool? The Scientific World Journal. Volume 2012, Article ID 173829, 10 pages. DOI: $10.1100 / 2012 / 173829$

Timofeeva S.S., Ulrikh D.V., Timofeev S.S. Phytomining Perspectives in Rehabilitation of Mining and Industrial Areas of South Ural. IOP Conference Series: Earth and Environmental Science. 2017. DOI:10.1088/1755-1315/66/1/012030.

${ }^{36}$ Ogoko E.C. Accumulation of Heavy Metal in Soil and Their Transfer to Leafy Vegetables with Phytoremediation Potential. American Journal of Chemistry. 2015. № 5(5): 125-131. 
it. Quickly displaces other grasses from the grass stand. The crop has a high winter and cold resistance, is drought-resistant and shade-tolerant, but does not tolerate a high level of underground water standing.

Tuberous rank (Lathyrus tuberosus) - a perennial, cold-resistant plant with a thin stem, a forage plant rich in proteins, thickened roots contain reserves of nutrients, known as a honey and ornamental plant. Tuberous rank prefers sandy loam and loamy soils, moderate humidity and neutral soil acidity.

The analysis of the content of trace elements in soils and plant samples showed that 37 elements of 26 exceed the ratio of the biological accumulation coefficient in B. inermis over $L$. tuberosus in 2-3 times, $\mathrm{Mn}$ (6.9 times), $\mathrm{Cd}$ (7.7 times) and Ge to 20 times. L. tuberosus accumulates other 5 elements $(\mathrm{Mg}, \mathrm{Cu}, \mathrm{Zn}, \mathrm{Mo}, \mathrm{Rh})$ more than B. inermis. It is 1-2 times more resistant to heavy metals and other toxic elements. $B$. inermis showed a greater ability to accumulate 32 elements out of 40 analyzed elements, while L. tuberosus actively accumulated only 8 elements. The ratio of concentrations of both useful and toxic elements, including heavy metals accumulated in the tissues of cereals and legumes are presented in the sequence: $\mathrm{P}>\mathrm{Mg}>\mathrm{Cu}>\mathrm{S}>\mathrm{Zn}>\mathrm{Mo}>\mathrm{Rh}>\mathrm{Re}$ (excess in the range from 2.5 to 1.0 times); $\mathrm{Ge}>\mathrm{Si}>\mathrm{Mn}>\mathrm{Cd}>\mathrm{Cr}>\mathrm{Co}>\mathrm{U}>\mathrm{Gd}>\mathrm{Tb}>\mathrm{Er}>\mathrm{Dy}>\mathrm{Tm}>\mathrm{Sm}>$ $\mathrm{Ho}>\mathrm{Nd}>\mathrm{Yb}>\mathrm{Lu}>\mathrm{Th}>\mathrm{Pr}>\mathrm{Ce}>\mathrm{Y}>\mathrm{Eu}>\mathrm{As}>\mathrm{Sc}>\mathrm{Al}>\mathrm{V}>\mathrm{La}>\mathrm{In}>\mathrm{Ga}>$ $\mathrm{Fe}>\mathrm{Ag}>\mathrm{Pb}$ (17.6-1.1 times).

The results of studies of biogeochemical indicators for rare elements in the reclaimed plots of mine heaps showed that most of the elements do not accumulate in plant tissues at concentrations higher than in soils. It was found that $\mathrm{Ge}$ accumulation in the root zone of B. inermis was 20 times greater than in L. tuberosus. At the same time, the L. tuberosus absorbed rhodium 1.04 times more than the $B$. inermis.

\section{CONCLUSIONS}

The ecohydrogeological background of reclaimed lands forming and exploration was worked out. It foresee an environment restoration of disturbed lands to manage flow down, atmospheric precipitations taking aside, the process of the reclaimed profile biogenetic horizons formation and promotion with total depth 1.0-1.2 $\mathrm{m}$ and involvement of more suitable rocks and artificial drainage building. The calculations of the groundwater table dynamics for reclaimed minelands (without and with horizontal drainage for irrigation) were conducted. The hydrochemical analyses of the potential sources of irrigation in the mining regions have approved prospects for some surface and underground waters using after soil alkalinity risk assessment.

The analysis showed a high reclamation potential of the studied plant species. The qualitative and quantitative composition of the mineral nutrition of plants affects the distribution and active growth of wild forms. The prospects for using the results of the case study are based on the possibility of Bromopsis inermis and Lathyrus tuberosus wild species using in 
experimental sites for coal heaps reclamation for phytoremediation and phytomining technologies.

\section{SUMMARY}

Current mining operations remove and replace overburden by strata with careful attention to preservation of topsoil to forthcoming land biological restoration and conservation make last decades. Environmental and health consequences in the surrounding area are minimal in case of Nikopol manganese deposit exploration. However, earlier mining operations did not preserve the integrity of the topsoil and underlying soil horizons. Therefore, even after leveling, the resulting "soil" is actually mixed-overburden substrata. A certain similarity of the tasks set earlier was recorded during the study of natural self-growth of reclaimed dumps of mine rocks in the Western Donbass. Some attention has recently been paid to the option of reclamation of the mine heaps with incorporation carbonated loess like loam layer as geomembrane to limit the toxicants migration. Further plans for this area reclamation are related to the previously proposed strategy for overburden rocks transformation into "young" soil after their long-term plant melioration. The use of red-brown clay for covering mine dumps allows to use its water-resistant properties to develop low-cost technology for saving water.

\section{REFERENCES}

1. Sheoran V., Sheoran A.S., Poonia P. Soil reclamation of abandoned mine land by revegetation: a review. International Journal of Soil, Sediment and Water. 2010. № 3(2). Art. 13. URL: http://scholarworks.umass.edu/ intljssw/vol3/ iss $2 / 13$

2. Menйndez J., Loredo J. Reclamation of Degraded Landscape due to Open Pit Coal Mining: Biomass for Renewable Power Plants. WSEAS Transactions on Environment and Development. 2018. № 14. P. 251-255. URL: http://www.wseas.org/multimedia/journals/environment/ 2018/a505915-aav.php

3. Borůvka L., Vacek O., Jehlička J. Principal component analysis as a tool to indicate the origin of potentially toxic elements in soils. Geoderma. 2005. № 128(3-4). P. 289-300. https://doi.org/10.1016/j.geoderma. 2005.04.010

4. Navarro M.C., Pérez-Sirvent C., Martínez-Sánchez M.J., Vidal J., Tovar P.J. \& Bech J. Abandoned mine sites as a source of contamination by heavy metals: A case study in a semi - arid zone. Journal of Geochemical Exploration, 2008. № 96(2-3). P. 183-193. https://doi.org/10.1016/ j.gexplo.2007.04.011

5 . Kuter N. Reclamation of degraded landscapes due to opencast mining. In Advances in Landscape Archtecture. Chapter 2013. № 33. P. 823-858. http://dx.doi.org/10.5772/55796 
6. Vondráčková T., Voštová V. \& Kraus M. Mechanization for Optimal Landscape Reclamation. IOP Conference Series: Earth and Environmental Science, 95, Art. 022042. http://doi.org/10.1088/1755-1315/95/2/022042

7. Kharytonov M.M., Resio Espejo J.M. Prospects of the Nikopol manganese basin rocks using for land reclamation. Gruntoznavstvo. 2013. Vol. 14(1-2). P. 78-86. http://www.ussj.cv.ua/2013_t14_1-2/index.html

8. Gould A.B., Hendrix J.W., Ferriss R.S. Relationship of mycorrhizal activity to time following reclamation of surface mine land in western Kentucky. I Propagule and spore population densities. Canadian Journal Botany. 1996. № 74. P. 247-261. https://doi.org/10.1139/b96-030

9. Macci C., Doni S., Peruzzi E., Bardella S. Filippis, G., Ceccanti B., Masciandaro G. A real-scale soil phytoremediation. Biodegradation. 2013. № 24(4). P. 521-538. https://doi.org/10.1007/s10532-012-9608-Z

10. Wong M.H. (2003). Ecological restoration of mine degraded soils, with emphasis on metal contaminated soils. Chemosphere. 2017. № 50(6). P. 775-780. https://doi.org/10.1016/S0045-6535(02)00232-1.

11. Le S.H., Ji W., Yang H.J., Kang S.Y., Kang D.M. Reclamation of mine-degraded agricultural soils from metal mining: lessons from 4 years of monitoring activity in Korea. Environ. Earth Sci. 2017. № 76. Art. 720. https://doi.org/10.1007/s12665-017-7076-9

12. Horvath B., Gruiz K., Sara B. Exotoxicological testing of soil by four bacterial biotests. Toxicological and Environmental Chemistry. 1997. № 58(1-4). P. 223-235. https://doi.org/10.1080/02772249709358412

13. Lugovaya Y.R., Orlova K.N., Litovkin S.V., Malchik A.G., Gaydamak M.A. Biotesting as a method of evaluating waste hazard in metallic mineral mining. Materials Science and Engineering, 2016. № 127. https://doi.org/10.1088/1757-899X/127/1/012026

14. Hanger M., Romantschuk M., Penttinen P-P., Egfors A., Marchand C., Augustsson A.. Assessing toxicity of metal contaminated soil from glassworks sites with a battery of biotests. Science of the Total Environment. 2018. P. 613-614, 30-38. https://doi.org/10.1016/j.scitotenv.2017.08.121

15. Dubova L., Limane B., Muter O., Versilovskis A., Zarina Dz., Alsina I. Effect of nitroaromatic compounds on the growth of potted plants. Current Research Topics in Applied Microbiology and Microbial Biotechnology. 2009. 24-28. https://doi.org/10.1142/9789812837554_0005

16. Tarika A.G., Zabaluev V.O. Mine land reclamation strategies in the Nikopol manganese ore basin (Central Steppe of Ukraine): Using replaced mining overburden in agriculture. 16th Int ${ }^{\prime}$ Conference, Society for Ecological Restoration, August 24-26, 2004, Victoria, Canada.

17. Kharytonov M. Geochemical assessment of reclaimed lands in the mining regions of Ukraine. NATO ARW Soil chemical pollution, risk assessment, remediation and security. Springer.Printed in the Netherlands. 2007. P. 57-60.

18. Wiche O., Szekely B., Kummer N.A., Moschner C., Heilmeier H. Effects of intercropping of oat (Avena sativa L.) with white lupin (Lupinus albus L.) on the mobility of target elements for phytoremediation and 
phytomining in soil solution. International Journal of Phytoremediation. 2016. DOI: $10.1080 / 15226514.2016 .1156635$.

19. Wiche O., Heilmeier H.. Germanium (Ge) and rare earth element (REE) accumulation in selected energy crops cultivated on two different soils. Minerals Engineering. 2016. № 92. P. 208-215.

20. Doležalová Weissmannová, H., Pavlovský, J. and Chovanec, P. Heavy metal Contaminations of Urban soils in Ostrava, Czech Republic: Assessment of Metal Pollution and using Principal Component Analysis. Int. J. Environ. Res. 2015. № 9(2). P. 683-696. ISSN: 1735-6865

21. Lu S.G. and Bai S.Q. Contamination and potential mobility assessment of heavy metals in urban soils of Hangz, China: relationship with different land uses. Environmental Earth Science. 2010. № 60. P. 1481-1490.

22. Legwaila I.A., Lange E., Cripps J. Quarry reclamation in England: a review of techniques. JASMR. 2015. № 4(2). P. 55-79. http://doi.org/ 10.21000/JASMR15020055

23. Kharytonov M., Mitsik O., Stankevich S., Titarenko O. 2013. Geomining site environment assessment and reclamation along coastal line of the Kerch Peninsula NATO Science for Peace and Security. Series C: Environmental Security, A. Vezirogluand M.Tsitskishvili (eds.). Chapter 27. P. 325-336. URL: http://link.springer.com/chapter/10.1007/978-94-0076152-0 27

24. Rudakov V.K. Methods of forecast calculation of irrigation impact on ground water regime. Issues of hydrogeological forecasts in connection with land irrigation and water supply. Issues of Scientific Research DSU. Dnepropetrovsk, 1970. Vol. 3. P. 5-97 (in Russian)

25. Kharytonov M.M. and Kroik A.A. Environmental Security of Solid Wastes in the Western Donbas Coal Mining Region, Ukraine. Environmental Security and Ecoterrorism, NATO Science for Peace and Security Series C: Environmental Security, H. Alpaset al. (eds.). 2011. P. 129-138.

26. Klimkina I., Kharytonov M., Zhukov M. Trend Analysis of WaterSoluble Salts Leaching Along Surfaces of Reclaimed Mine Dumps in Western Donbass (Ukraine). Environmental Research, Engineering and Management. 2018. Vol. 74. No 2. P. 82-92

27. Maiti S.K., Ghose M.K. Ecological restoration of acidic coal mine overburden dumps - on Indian case study. Land Contamination and Restoration. 2005. № 13(4). P. 361-369. http://dx.doi.org/ $10.2462 / 09670513.637$

28. Baderna D., Lomazzi E., Pogliaghi A., Ciaccia G., Lodi M., Benfenati E. Acute phytotoxicity of seven metals alone and in mixture: Are Italian soil threshold concentrations suitable for plant protection? Environmental Research. 2015. № 140. P. 102-111. https://doi.org/10.1016/ j.envres.2015.03.023

29. Nikolaeva O.V., Terekhova V.A. Improvement of laboratory phytotest for the ecological evaluation of soils. Eurasian Soil Sc. 2017. № 50(9). P. 1105-1114. https://doi.org/10.1134/S1064229317090058 
30. Chaignon V., Hinsinger P. A Biotest for Evaluating Copper Bioavailability to Plants in a Contaminated Soil. Journal of Environmental Quality, 2003. № 32. P. 824-833. https://doi.org/10.2134/jeq2003.8240

31. Baranov V.I., Knish I.B., Blaida I.A., Vaschuk S.P., Gavriljak M.J. Cane - phytoremediant of heavy metals in drainage ditch rock dump coal mines. Biol. Stud. 2012. № 6(1). P. 93-100. https://doi.org/10.30970/ sbi.0601.18

32. Boehmel C, Lewandowski I, Claupein W. Comparing annual and perennial energy cropping systems with different management intensities. Agricultural Systems. 2008. Vol. 96(1-3). P. 224-236. https://doi.org/ 10.1016/j.agsy.2007.08.004

33. LaţoA., Radulov I., Berbecea A., Laţo K., Crista F.. The transfer factor of metals in soil-plant system. Research Journal of Agricultural Science. 2012. № 44 (3). P. 67-72.

34. Hector M. Conesa, Michael W. H. Evangelou, Brett H. Robinson and Rainer Schulinю A Critical View of Current State of Phytotechnologies to Remediate Soils: Still a Promising Tool? The Scientific World Journal. Volume 2012, Article ID 173829, 10 pages. DOI:10.1100/2012/173829

35. Timofeeva S.S., Ulrikh D.V., Timofeev S.S. Phytomining Perspectives in Rehabilitation of Mining and Industrial Areas of South Ural. IOP Conference Series: Earth and Environmental Science. 2017. DOI:10.1088/1755-1315/66/1/012030.

36. Ogoko E.C. Accumulation of Heavy Metal in Soil and Their Transfer to Leafy Vegetables with Phytoremediation Potential. American Journal of Chemistry. 2015. № 5(5). P. 125-131.

\section{Information about authors:} Kharytonov M. M., Doctor of Agricultural Sciences, Professor, Professor Soil Science and Farming Department Dnipro State Agrarian and Economics University

25, Yefremov str., Dnipro, 49000, Ukraine

Klimkina I. I., Associate Professor, Dr., Department of Ecology and Environmental Technologies, Dnipro University of Technology 19,Dmytro Yavornytskiy Av., Dnipro, 49005, Ukraine

Wiche O.,

Dr., Institute of Life Sciences

TU Bergakademie Freiberg 29, Leipziger Straße, Zimmer 13, Freiberg, Germany 